\title{
Field evaluation of Musa germplasm for resistance against banana stem weevil, Odoiporus longicollis (Oliver) (Curculionidae: Coleoptera) in Kadapa district of Andhra Pradesh
}

\author{
D. Srinivasa Reddy ${ }^{*}$, C. Madhumathi ${ }^{2}$, H. Naveena ${ }^{1}$ and L. Rajesh Chowdary ${ }^{3}$ \\ ${ }^{1}$ Department of Agricultural Entomology, Horticultural College and Research Institute, DRYSRHU, Ananthrajupeta \\ -516105, Koduru, District Kadapa (Andhra Pradesh), INDIA \\ ${ }^{2}$ Department of Horticulture, Horticultural Research Station, DRYSRHU, Ananthrajupeta-516105, Koduru, District \\ Kadapa (Andhra Pradesh), INDIA \\ ${ }^{3}$ Department of Agricultural Entomology, Main Agricultural Research Station, Raichur (Karnataka), INDIA \\ *Corresponding author. E-mail: dsr2020@gmail.com
}

Received: August 29, 2014; Revised received: January 22, 2015; Accepted: January 25, 2015

\begin{abstract}
Banana germplasm with 17 different accessions for resistance were screened against banana stem weevil, Odoiporous longicollis in Koduru region of Kadapa district (Andhra Pradesh). All the accessions had infestation of stem weevil but with varying percent infestation. The 17 accessions of germplasm had weevil infestation ranging from 10.0-100 percent in 2012 with maximum infestation of 100 percent in red banana (AAA genome) followed by Bontha selection-88.88 \% (ABB), Karpuravalli-84.60\% (AAB) and Ellakibale-64.7\% (AB) and the lowest was in Sugandhalu-10.00\% (AAB). In the year 2013, the infestation was in the range of $13.00-90.40 \%$ and with respect to infestation levels in different accessions, and the trend remained same as the earlier year wherein the highest infestation was recorded in red banana- $90.40 \%$ followed by Bontha selection with the damage of $83.50 \%$, Karpuravalli (79.80\%), Ellakibale (70.00\%) and least in Sugandhalu-13.0\% (AAB). There was no correlation between number of adults observed and percent damage and similarly no relation can be drawn between percent infestation and height of oviposition, This implies that the infestation caused by the weevils varied in different genotypes and also this information will be further helpful in selecting the resistant germplasms for future.
\end{abstract}

Keywords: Banana, Germplasm, Musa, Resistance, Stem weevil

\section{INTRODUCTION}

Bananas are of great economic importance in most regions of tropical and subtropical countries. Bananas and Plantains constitute the fourth most important crop of the developing world and India is the largest producer in the world. Of the 40 million tonnes of fruits produced in India (Gailce Leo Justin et al., 2008), banana occupies the top position with an annual output of 13.5 MT from an area of 40,000ha. Insect pests play a major role in reducing yield and quality. Their all year-round production ensures a continuous supply of food and income to the farmer, making bananas a major food security crop in the region. However, banana productivity has failed to keep pace with increasing food demand despite the steady increase in banana acreage over the past 30 years (Sebuwufu et al., 2004). More than 180 species of insect pests have been recorded on banana world over (Simmonds, 1966) of which 30 are major (Wadhi and Batri,1964). In India, nineteen species have been reported to infest banana (Padmanaban and Sathiamoorthy, 2002a) and of these, the banana stem weevil (BSW), known as pseudo stem weevil/pseudo stem borer. Odoiporus longicollis Olivier (Coleoptera: ISSN : 0974-9411 (Print), 2231-5209 (Online) All Rights Reserved @ Applied
Curuclionidae) is a serious pest causing heavy loss to the grower which affects both production and productivity of bananas and plantains (Ostmark, 1974). The extreme infestation of the BSW make the pseudo stem weak and thus reduce the rate of flowering of the plant and finally result in undersized fruiting or no fruiting at all (Dutt and Maiti, 1972). It has been estimated that the stem weevil causes $10-90 \%$ yield loss depending on the infestation stage and management efficiency. Because of the long lifespan of adults (live up to 200 days) and endophytic behavior of the larvae, conventional method of control, especially chemical control proved to be less effective (Padmanaban et al., 2001). In this context management of the pest without harm to non-target species and the environment is a prerequisite and one such method seems to be screening of germplasm for resistance to weevil and a wide range of Musa germplasm has been screened for weevil in Africa and Asia (Kiggundu et al., 2003a) and the large variability in weevil response observed in Musa germplasm suggested that useful sources of weevil resistance are available in the Musa germplasm (Kiggundu et al., 2003b). Though Charles et al. (1996) evaluated banana cultivars against banana stem weevil but only in limited number. Hence Natural Science Foundation www.ansfoundation.org 
a study was been undertaken for Musa germplasm screening against $O$. longicollis. This study aimed to investigate the infestation levels of seventeen different genotypes which can be further used as resistance source.

\section{MATERIALS AND METHODS}

The study was carried out at Horticultural Research Station (HRS), Anantharajupet, Koduru, Andhra Pradesh. Banana germplasm available at the Horticultural Research Station (HRS) of Dr. Y. S. R. Horticultural University, Anantharajupet was evaluated under field conditions against pseudostem weevil, during 2012 and 2013. There were totally seventeen genotypes evaluated under field conditions viz., Bontha selection, Pisong Raja, Karpuravalli, Nukala Bontha, Nendran, Kanthali, Virupakshi, CO-1, Sirumalai, Ellakibale, Ayrenka Rasthalu, Chinia, Sugandhalu, Bharat Rathnavali, Red Banana, Mattipoovan and Rasthali. The crop was raised during 2010 with row to row and plant to plant distance of $1.8 \times 1.8 \mathrm{~m}$, respectively and the normal package of practice recommended by Dr. Y.S.R. Horticultural University was followed. Twelve banana plants per genotype and per treatment were assessed for weevil damage at bunch maturity of the plant crop. The observations were recorded on number of damaged plants for both the years and mean percent damage was worked out for each germplasm (Padmanaban et al., 2001). Highly infested plants were cut open to record the number of adult weevils and grubs inside the plant in each treatment.

\section{RESULTS AND DISCUSSION}

Field evaluation of banana germplasm carried out for 2 years against pseudostem weevil indicated that the weevil attacked all the banana germplasm available at Horticultural Research Station (HRS) farm but with a different degree of percent infestation. It was observed 17 accessions belonging to $\mathrm{ABB}, \mathrm{AAB}, \mathrm{AB}$ and $\mathrm{AAA}$ had weevil infestation (Table 1). The infestation ranged from $10.0-100 \%$ in 2012 compared to 13.00 $-90.40 \%$ during 2013. In 2012, maximum infestation of $100 \%$ was noticed in the AAA genome, red banana followed by $\mathrm{ABB}$ genome i.e. Bontha selection with $88.8 \%$. In conformity of our findings, highest level of infestation was noticed on Nendran followed by red Banana as reported by Jayanthi and Verghese (1999). In other accessions of ABB genome, Karpuravalli and Nukalabontha had 84.6 and 60.0 percent infestation, respectively. One accession belonging to $\mathrm{AB}$ genome, Ellakibale, had $64.7 \%$ infestation. Accordingly, Jayanti and Verghese (1999) reported 100 percent loss on cultivar Elakki. Higher infestation of more than $60 \%$ was also observed in our accessions belonging to $\mathrm{AAB}$ genome (Nendran and Virupakshi), whereas in other accessions the weevil infestation ranged from 16.6 to $54.5 \%$ in 2012. In a study, Visalakshi et al. (1989) reported that the varieties Nendran and Red Kappa were highly susceptible.

In 2013, though the percent banana stem weevil infestation was lower compared to 2012 in all the accessions, but similar trend of observation was recorded in former year, where red banana of AAA genome had maximum weevil infestation of $90.40 \%$ followed by Bontha selection of $\mathrm{ABB}$ genome with $83.5 \%, 79.8 \%$ in Karpuravalli of $\mathrm{AAB}$ genome, Ellakibale of $\mathrm{AB}$ genome with $70.0 \%$ and Nendran of $\mathrm{AAB}$ genome with $66.2 \%$. In other 11 accessions of $\mathrm{AAB}$ and one $\mathrm{ABB}$ genome, weevil infestation

Table 1. Percent infestation of banana germplasm with stem weevil, $O$. longicollis.

\begin{tabular}{llcc}
\hline Genome & Local name & \multicolumn{2}{c}{ Percent infestation } \\
\cline { 3 - 4 } & & $\mathbf{2 0 1 2}$ & $\mathbf{2 0 1 3}$ \\
\hline ABB & Bontha selection & 88.8 & 83.5 \\
AAB & Pisong Raja & 50.0 & 42.0 \\
ABB & Karpuravalli & 84.6 & 79.8 \\
ABB & Nukala Bontha & 60.0 & 53.0 \\
AAB & Nendran & 64.3 & 66.2 \\
AAB & Kanthali & 35.3 & 34.0 \\
AAB & Virupakshi & 62.5 & 57.8 \\
AAB & CO-1 & 54.5 & 48.0 \\
AAB & Sirumalai & 50.0 & 52.0 \\
AB & Ellaki Bale & 64.7 & 70.0 \\
AAB & Ayrenka Rasthalu & 35.7 & 41.0 \\
ABB & Chinia & 16.6 & 18.0 \\
AAB & Sugandhalu & 10.0 & 13.0 \\
ABB & Bharat Rathnavali & 33.3 & 35.0 \\
AAA & Red Banana & 100.0 & 90.4 \\
AAB & Mattipoovan & 26.6 & 30.0 \\
AAB & Rasthali & 52.0 & 48.0 \\
\hline
\end{tabular}


Table 2. Plant height observed for oviposition and number of adults found in each germplasm.

\begin{tabular}{llcc}
\hline Genome & Local name & $\begin{array}{c}\text { Range of plant height preferred for } \\
\text { oviposition (cm) }\end{array}$ & Adults \\
\hline ABB & Bontha selection & $15-148$ & 9 \\
AAB & Pisong Raja & $20-200$ & 13 \\
ABB & Karpuravalli & $20-285$ & 21 \\
ABB & Nukala Bontha & $55-176$ & 6 \\
AAB & Nendran & $12-112$ & 4 \\
AAB & Kanthali & $75-142$ & 2 \\
AAB & Virupakshi & $0-200$ & 5 \\
AAB & CO-1 & $38-143$ & 2 \\
AAB & Sirumalai & $12-135$ & 3 \\
AB & Ellaki Bale & $27-216$ & 5 \\
AAB & Ayrenka Rasthalu & $52-168$ & 6 \\
ABB & Chinia & $0-126$ & 2 \\
AAB & Sugandhalu & $47-133$ & - \\
ABB & Bharat Rathnavali & $35-150$ & 3 \\
AAA & Red Banana & $45-127$ & 11 \\
AAB & Mattipoovan & $45-159$ & 12 \\
AAB & Rasthali & $65-120$ & 4 \\
\hline
\end{tabular}

ranged from 18.00 to $57.80 \%$.

Thippaiah et al. (2010) observed that Chandrabale was the most susceptible variety and Rasabale was the least susceptible variety to pseudostem weevil and they also further noted that variety Nendran $(9.03 \%)$, Poovan (7.57\%), and Elakki (6.30\%) were also susceptible. Accordingly, Padmanaban and Sundaraju (1999) and Anitha (2004) recorded intermediate level of infestation on the clones of Palayankodan and Poovan.

One accession by local name Sugandhalu of AAB genome had minimum infestation in both the years under observation. It has been observed that the number of insect stages found cannot be correlated to percent damage. Maximum number of adults (Table 2) were found in Karpuravalli (21 nos) followed by Pisong Raja, Mattipoovan and red banana where as in Kanthali, CO-I and Chinia only two adults were found which had 35.30 and 34.0; 54.5 and 48.0, 16.6 and $18.0 \%$, in 2012 and 2013, respectively. It was also further recorded that in the infested plants, 3-5 grubs were found. In confirmation of our observation Padmanaban and Sundaraju (1999) observed 2-15 adult weevils, 10- 15 grubs and 5-8 pupal cases in the banana stem weevil infested plants. It was further interesting to observe that in case of one genome (AAA) i.e. red banana the insect has tunneled extensively all the leaf sheaths (16nos) into the pseudostem and damaged even the floral stem indicating the severity of damage to the crop.

In regard to plant height observation with respect to oviposition (Table 2), in some varieties like, Sirumalai and Nendran, even at minimum height of $12 \mathrm{~cm}$ from ground level oviposition was observed as compared to maximum height of $188 \mathrm{~cm}$ in tall varieties like Karpuravalli indicating that there was no relation between plant height and infestation levels. In support of our findings, Padmanaban et al. (2001) studies indicated that there was no relation between infestation, stem girth and plant height with even smaller plants being infested but contrary Dutt and Maiti (1972) have reported that the portions of the banana pseudostem with circumference ranging from 25 to $50 \mathrm{~cm}$ and up to a height of $125 \mathrm{~cm}$ in tall varieties like Martaman (AAB), Champa (AAB) and Kanchekala (ABB) and up to a height of $100 \mathrm{~cm}$ in dwarf varieties like Kabuli (AAA) are the preferred sites for oviposition.

\section{Conclusion}

In conclusion, the differences in damage and larvae density clearly separated the susceptible from the resistant from the percent infestation data and it was reviewed that the banana cultivars grown by farmers in the Kadapa region other than Grand Naine are Sugandhalu, Rasthali and Karpooravalli (Local name-Nellore Amruthapani) are also susceptible to BSW and same findings has been recorded in the random survey carried out in the dominantly grown banana regions in the Kadapa district for three years, indicating that this insect pest, $O$. longicollis has to be managed by non chemical means. The study finally revealed the susceptible and resistant 
genotypes based on the infestation levels of the weevil and this information can be further useful for breeding of resistant cultivars against $O$. longicollis

\section{REFERENCES}

Anitha, N. (2004). Clonal susceptibility and age preference of banana pseudostem weevil, Odoiporus longicollis Olivier. Insect Environment, 10:132-34.

Charles, J.S.K., Thomas, M.J., Menon, R., Pramalatha, T. and Pillai, S.J. (1996). Field susceptibility of banana to Pseudostem borer, Odoiporus longicollis (Oliv.). in Symposium on technological advancement in bananal plantain production and processing-India- International Abstracts of papers. (N.K.Nayar \& T.E. George, eds.). P.32. 20-24 Aug. 1996. Kerala Agricultural University, Mannuthy, India.

Dutt, N. and Maiti, B.B. (1972). Bionomics of the banana Pseudostem weevil, Odoiporus longicollis (Coleoptera : Curculionidae). Indian Journal of Entomology, 34: 20 -30 .

Gailce Leo Justin, Leelamathi, M and Nirmaljohson, S.M. (2008). Bionomics and management of pseudostem weevil Odoiporus longicollis Olivier (Coleoptera: Curculionidae) in banana-A review. Agriculture Review. 29(3):185-192.

Jayanthi, P.D.K. and Verghese, A. (1999). Report of the occurrence of banana weevils in Bangalore. Insect Environment, 4: 153.

Kiggundu, A., Gold, C.S., Labuschagne, M., Vuylsteke, H. K., Louw, S.V.D.M. (2003a). Levels of host plant resistance to banana weevil Cosmopolites sordidus (Germar) (Coloeptera: Curculionidae) in African Musa germplasm. Euphytica, 133: 267-277.
Kiggundu, A., Pillay, M., Viljoen, A., Gold, C., Tushemereirwe, W. and Kunert, K. (2003b). Enhancing banana weevil (Cosmopolites sordidus) resistance by plant genetic modification. A perspective. African Journal of Biotechnology, 2: $563-569$.

Ostmark, H.E. (1974). Economic Insect Pests of Bananas. Annual Review of Entomology, 19: 161-176.

Padmanaban, B and Sundaraju, P. (1999). Occurrence of banana weevil borers (Coleoptera : Curculionidae) in Tamil Nadu. Insect Environment, 5: 135.

Padmanaban, B., Sundaraju, P., Velayudhan, K.C. and Sathiamoorthy, S. (2001). Evaluation of Musa germplasm against banana weevil borers. Infomusa, 10(1): 26-28.

Padmanaban, B. and Sathiamoorthy, S. (2002a). Present status of banana stem weevil in India. Global Conference on banana and plantain, Bangalore, 178.

Sebuwufu, G., Rubaihayo, P.R. and Blomme, G. (2004). Variability in the root system of East African banana genotypes. African Crop Science Journal 12: 85-93.

Simmonds, N. W. (1966). Bananas. Second Edition. Longman, London.pp: 208-241.

Thippaiah, M., Ashok Kumar, C.T., Shivaraju, C. and Chakravarthy, A. K. (2010). Incidence of Banana Pseudostem Weevil, Odoiporus longicollis (Olivier) in South Karnataka. Pest Management in Horticultural Ecosystems, 16: 50-53.

Visalakshi, A., Nair, G.M., Beevi, S.N. and Amma, A.M.K. (1989). Occurrence of Odoiporus longicollis (Oliv.) (Coleoptera : Curculionidae) as a pest of banana in Kerala. Entomon, 14(3): 367-368.

Wadhi, S.R. and Batri, H.N. (1964). Pests of tropical and sub tropical fruit trees. pp: 227-260. Pant N C (ed.). Entomology in India, Entomological Society of India. New Delhi. 